\title{
The North Greenland Project
}

\author{
Niels Henriksen and A. K. Higgins
}

\begin{abstract}
The background for the North Greenland Project, one of the largest and most ambitious geological programmes undertaken by the Geological Survey of Greenland, is outlined. Aspects of the physiography and history of research are briefly recounted prior to a discussion of the cartographic and logistic problems associated with field work along the northern coast of Greenland. The principal scientific results of the project are enumerated.
\end{abstract}

N. H. \& A. K. H., Geological Survey of Greenland, Øster Voldgade 10, DK-1350 Copenhagen $K$, Denmark.

The first areas to be investigated when the Geological Survey of Greenland (Grønlands Geologiske Undersøgelse, GGU) was established shortly after the Second World War were the more easily accessible parts of West and South-West Greenland (Fig. 1). These regions are part of the Precambrian Shield which dominates Greenland and, as a consequence, GGU initially developed into an institution specialised in 'hard rock' geology. From the mid-1950s a systematic programme aimed at the production of 1:100 000 geological maps was begun in South-West Greenland. A complementary 1:500 000 mapping programme was initiated in 1964 with the aim of establishing a general geological overview of the entire ice-free part of Greenland within the foreseeable future (Fig. 2). This work began in West Greenland and continued in East Greenland after $1: 100000$ mapping (1968-72). By the early 1970 s North Greenland had also come into focus as a 1:500 000 mapping target.

A primary aim of the 1:500 000 programme is to establish a geological foundation which will facilitate the exploitation of mineral resources in Greenland. In some areas, such mapping can be based on information derived from the existing 1:100 000 programme. In other areas, special ship-based or helicopter-supported field programmes, supported by photogeological interpretation, are necessary to provide the required geological data to supplement existing information.

North Greenland presented a special catalogue of problems. Unlike the Precambrian crystalline terranes of West Greenland, North Greenland is dominated by
Proterozoic and Phanerozoic sedimentary basins, variously affected by mid-Palaeozoic and Tertiary orogenies (Map 1). The area had been little visited since a brief early period of exploration, although all available geological information and a large-scale reconnaissance photo-interpretation had been integrated to provide a synthesis of the regional geology (Dawes, 1971; 1976). A new approach to the 1:500 000 mapping programme was necessary in terms of logistics in the remote areas of North Greenland and, in formulating the North Greenland Project, GGU came to adopt and adapt techniques used by geologists in the adjacent Canadian Arctic to cope with the investigation of large tracts of sedimentary rocks.

The growth of the North Greenland Project into one of the largest and most ambitious work programmes ever undertaken by GGU was influenced by the increasing interest in economic exploitation of the Arctic. Activities by government and commercial agencies in the high Arctic of Canada had earlier reached parts of North Greenland. In 1965-66 two GGU geologists joined the Geological Survey of Canada 'Operation Grant Land' which worked in Ellesmere Island and the Washington Land - Wulff Land area of western North Greenland (cf. Dawes, 1984; Dawes \& Peel, 1984).

Commercial activity in the Innuitian region of northern Canada was extended to Greenland in 1969 when the Canadian organisation of J. C. Sproule and Associates commenced a regional geological survey of northern Greenland for Greenarctic Consortium, a programme that included a regional aeromagnetic survey. 


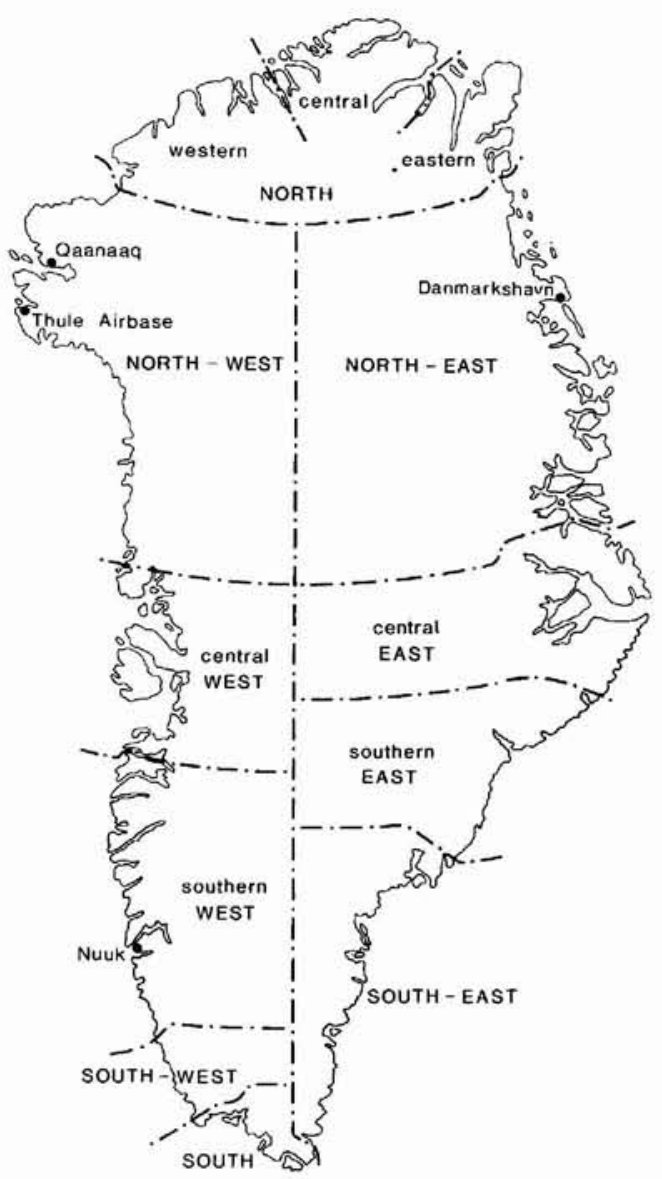

Fig. 1. Locality map.

Field work undertaken by GGU as a preliminary to the North Greenland project was initiated in 1974 with reconnaissance in Peary Land (Peel \& Christie, 1975; Christie \& Peel, 1977). From 1975 to 1977 field teams worked in Daugaard-Jensen Land and Washington Land, with short visits to Hall Land and Inglefield Land (Henriksen \& Peel, 1976; Peel, 1977, 1978).

The North Greenland Project itself was divided into two phases, the first phase from 1978 to 1980 covered the Peary Land to Kronprins Christian Land region, and the second (1984-85) concentrated on the area from Petermann Gletscher to J. P. Koch Fjord (Map 1). This corresponds to the area covered by 1:500 000 maps sheets 7 and 8 (Fig. 2), although field investigations were carried out in areas adjacent to the map sheet areas as geological problems dictated. Acquisition of a regional geological understanding sufficient for the production of these map sheets was a primary goal of the project, although a variety of other activities were also encompassed. Yearly summaries of project activities are given in volumes 88, 99, 106, 126 and 133 of Rapport Grønlands geologiske Undersøgelse. A summary of the many papers and maps resulting from the project is given below

\section{Physiography and climate}

Geological activities associated with the North Greenland project extended from northern Washington Land in the west to southern Kronprins Christian Land in the east, a distance of more than $1000 \mathrm{~km}$. The region, north of the Inland Ice, is up to $250 \mathrm{~km}$ wide from north to south with a land area of about 130000 $\mathrm{km}^{2}$. The physiography varies widely, reflecting both the high Arctic setting and the influences of geology.

The Arctic Ocean and the fjords of North Greenland are ice-covered all the year round, although the innermost parts of a few fjords may be ice-free in August and early September. Open-water leads form in the

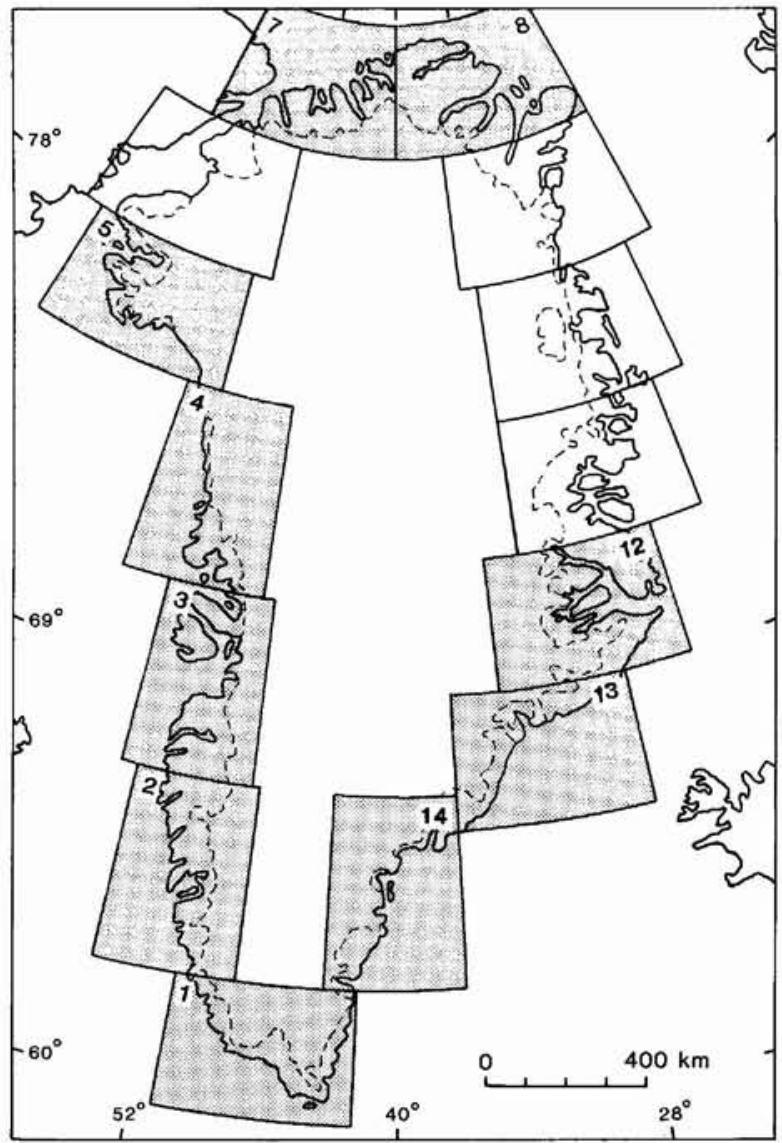

Fig. 2. Index to the 1:500 000 geological map series of Greenland. Ten of the 14 sheets are published or in press. Sheets 7 (Nyeboe Land) and 8 (Peary Land) cover most of the area surveyed by the North Greenland Project. 


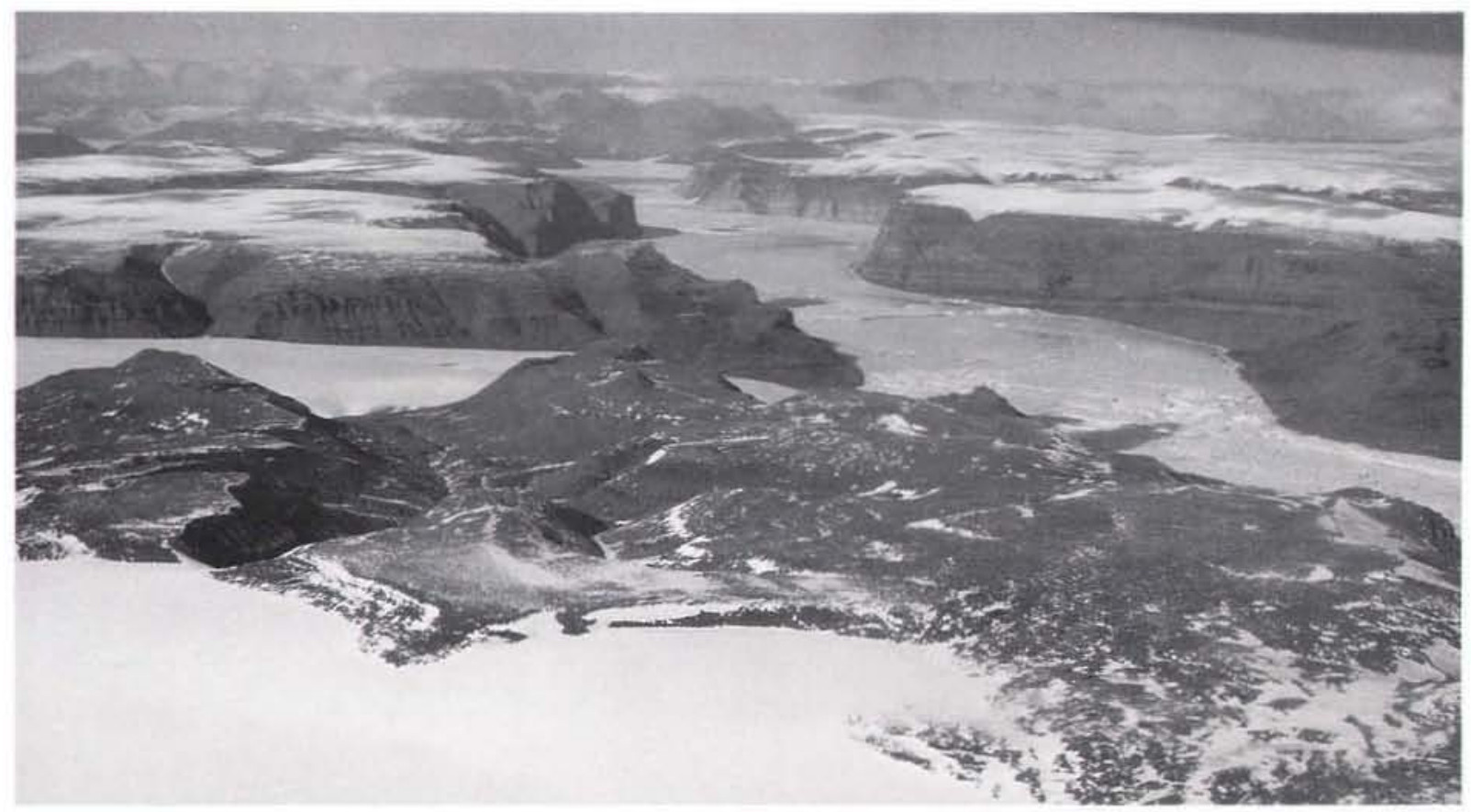

Fig. 3. Plateau landscape with local ice caps formed in gently dipping Cambrian-Silurian sediments; the plateau surface rises to more than $1000 \mathrm{~m}$. View looking north across Lauge Koch Land and Ekspedition Bræ (centre left), down J. P. Koch Fjord which is covered with semi-permanent sea ice.

summer in the Arctic Ocean ice, notably at the contact between the stationary fjord ice and the drifting ice pack. Hydrographic conditions in the fjords are poorly known, although some geophysical information exists for Nares Strait and parts of the continental margin facing the Arctic Ocean (Dawes, 1990).

The Inland Ice, the major glaciers which drain it, and the many local ice caps are prominent features of the region. The Inland Ice margin can be traced as an undulating line across the region, and has an altitude of generally $600-800 \mathrm{~m}$ where it abuts against the ice-free ground to the north. The numerous glaciers draining from the Inland Ice to the heads of the fjords range up to $15 \mathrm{~km}$ in width (Map 1), and the larger glaciers have velocities mainly in the range of $300-500 \mathrm{~m}$ per year; Petermann Gletscher has advanced $17 \mathrm{~km}$ in 19 years, an average annual velocity of almost $900 \mathrm{~m}$ (Higgins, 1988).

Independent local ice caps are promiment in Peary Land, Freuchen Land and Kronprins Christian Land. They occur at altitudes of about $1000 \mathrm{~m}$ and may be more than $70 \mathrm{~km}$ across. Alpine glacier systems are conspicuous in Nansen Land, Johannes V. Jensen Land and parts of Kronprins Christian Land.

The topography of the ice-free areas of North Greenland clearly reflects the influence of the former ice cover during the last glacial maximum (Funder \& Hjort, 1980; Kelly \& Bennike, 1985; Bennike \& Kelly, 1990). Glacier-eroded $\mathrm{U}$-shaped valleys cut through the landscape, radiating out from the Inland Ice or local glaciation centres. Relief in these valleys varies from a few hundred metres to over $1000 \mathrm{~m}$. Glacial deposits are widespread. Moraine occurs at all altitudes, whereas fluviatile Quaternary deposits are confined to valley floors.

In areas to the south, where the geology is characterised by flat-lying, mainly sedimentary sequences, geomorphological expression generally takes the form of a plateau landscape with summits reaching $800-1200 \mathrm{~m}$, dissected by steep-sided valleys or fjords (Fig. 3). Plateau forms vary from place to place, depending on the local rock types. Alternating sandstone and siltstone sequences of the Silurian turbidite succession and massive Cambrian-Silurian carbonate units have extensive outcrops; in the south-east Proterozoic basalts and associated carbonate and siliciclastic sediments are conspicuous.

Areas formed by folded and metamorphosed rocks, such as Nansen Land and Johannes V. Jensen Land in the North Greenland fold belt and parts of Kronprins Christian Land in the East Greenland Caledonian fold belt, are characterised by alpine relief and support inde- 


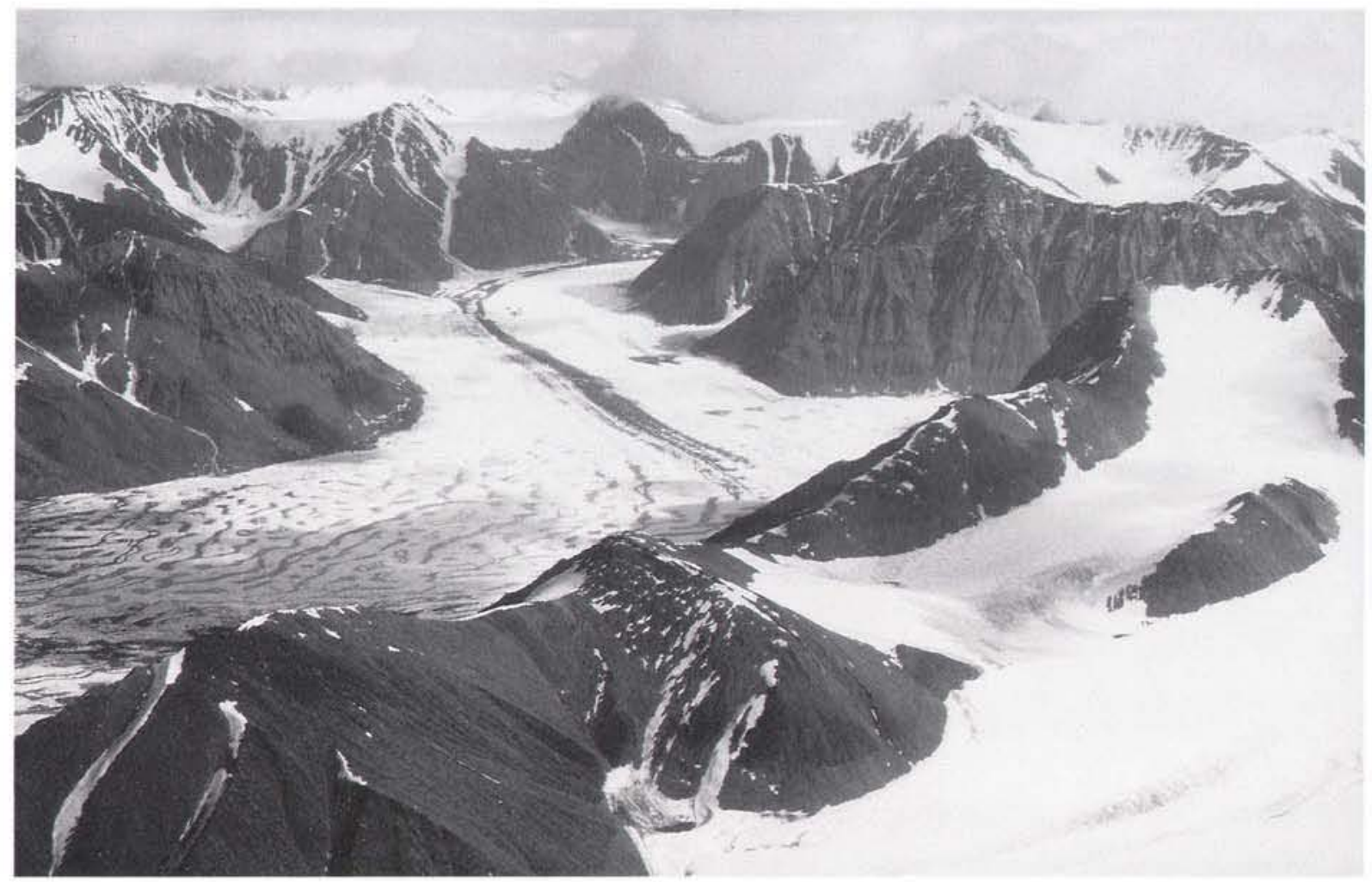

Fig. 4. Alpine landscape in the North Greenland fold belt, western Johannes V. Jensen Land. Mountain summits approach $2000 \mathrm{~m}$.

pendent valley glacier systems (Fig. 4). The highest peak in the area, Helvetia Tinde in Johannes V. Jensen Land, reaches an altitude of $1930 \mathrm{~m}$.

Climatic records for North Greenland include those made at stations at Jørgen Brønlund Fjord (1948-52) and Kap Harald Moltke (1973-87) by the Danish Peary Land expeditions, and more continuous records made at Station Nord (1950-72). In recent years, the establishment of five unmanned automatic weather stations in North Greenland by the Danish Meteorological Institute has provided better regional control and continuous records of basic weather data. The latter show the annual mean temperature for the region to range from $-20^{\circ} \mathrm{C}$ to $-17^{\circ} \mathrm{C}$, with average winter temperatures as low as $-40^{\circ} \mathrm{C}$ and average summer temperatures of up to $+5^{\circ} \mathrm{C}$. Annual precipitation, mainly as snow, is estimated at 100-200 mm (P. Frisch, personal communication, 1990).

Winds are mainly katabatic, and are strongest in a 30 $\mathrm{km}$ wide zone near the Inland Ice margin. In coastal areas summer winds are sea breezes formed due to temperature contrasts between the land and ice-covered sea, and fog developments are common. There is mid- night sun from mid-April to early September, and total darkness from late October until late February.

Working conditions during the project's summer field seasons were generally very favourable, with stable weather and little precipitation. Coastal fog was the most usual cause of lost working days. At the beginning of some seasons the thaw of local extensive snow cover could produce the practical difficulty of very wet conditions.

\section{History of research}

Summaries of the geology of North Greenland and its history of exploration prior to the start of the North Greenland project include those of Dawes (1971, 1973, 1976, 1987), Dawes \& Christie (1982), Dawes \& Haller (1979), Dawes \& Soper (1973) and Christie \& Dawes (in press). A geological map at a scale of about 1:1 500000 accompanies Dawes (1976).

North Greenland is uninhabited, apart from a handful of military personnel maintaining the gravel airstrip at Station Nord (Fig. 5). The nearest permanent civilian settlement is at Qaanaaq, near Thule Air Base in North- 


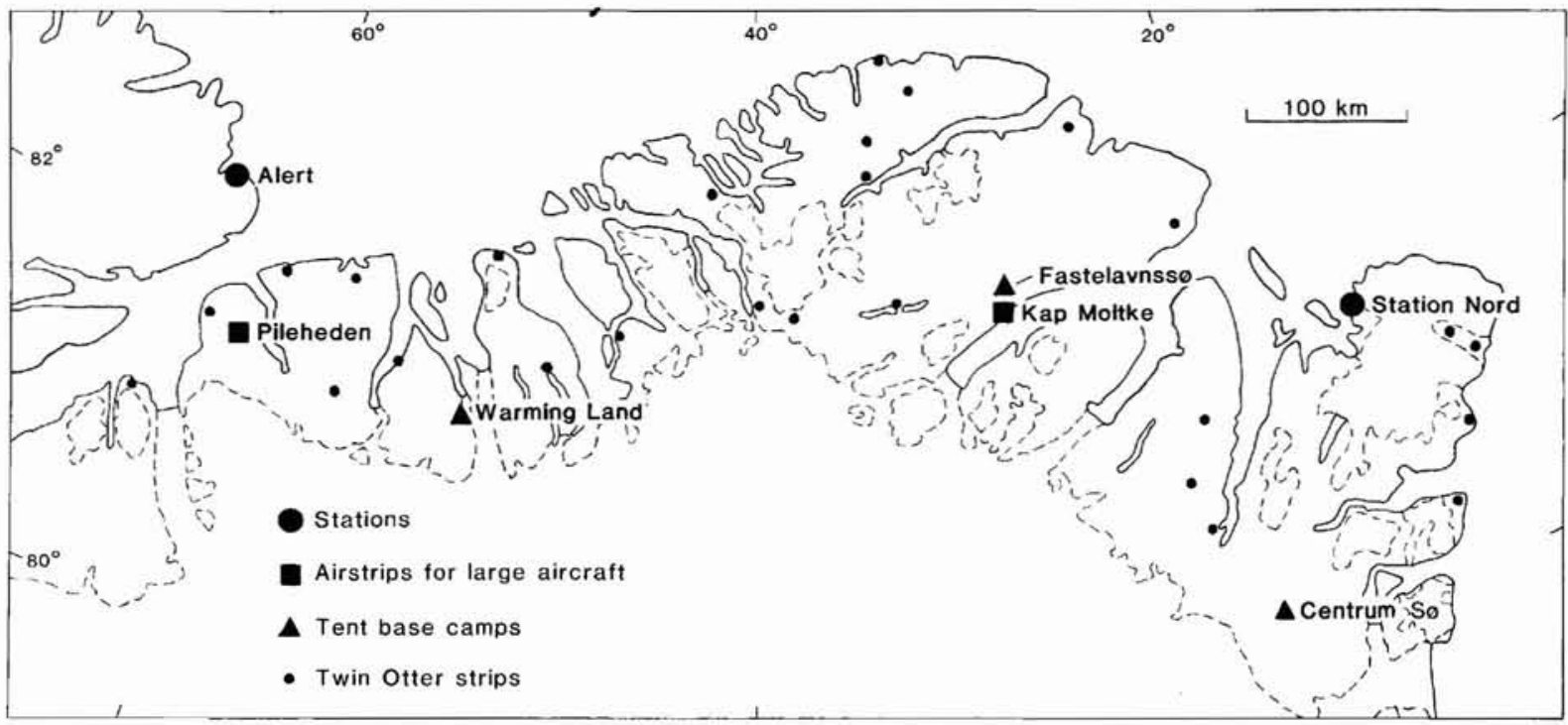

Fig. 5. Map of North Greenland and adjacent Ellesmere Island showing the location of permanently manned stations capable of receiving large aircraft, tent base camps established by GGU in connection with the North Greenland Project and natural landing strips.

West Greenland, the principal point of access to the region (Fig. 1). North Greenland, however, was inhabited by palaeo-Eskimos as far back as 4300 years ago (Independence I culture), and a succession of cultures (Independence II, 700 B.C.; Dorset, 100 B.C. - A.D. 700; Thule, A.D. 900 - A.D. 1200) indicate a long history of Inuit habitation.

The earliest written records and geological observations concerning North Greenland relate to late 19th century voyages of geographical discovery in pursuit of the North-West Passage or the North Pole. In the early decades of this century Danish dog-sledge expeditions assumed a leading role in the exploration of North Greenland. The activities of one man - Lauge Koch (1892-1964) - are pre-eminent in providing the geological and cartographical framework upon which subsequent studies of North Greenland geology have been based. The considerable scientific results of expeditions in which he was a participant include a series of topographic maps at 1:300 000 (Koch, 1932), five geological maps (see summary by Dawes \& Haller, 1979) and several geological syntheses (Koch, 1925, 1929, 1935).

The introduction of aircraft-support for expeditions in the years immediately following the Second World War marked the beginning of the modern age of North Greenland geology, although it was first during 'Operation Groundhog' in 1958-60 that aircraft were integrated into daily geological field work (Davies et al., $1959,1963)$. The true potential of aircraft-based logis- tics was fully exploited by the North Greenland Project, with two helicopters and a fixed-wing Twin Otter continuously supporting the expedition in the field.

\section{Project formulation and preparation}

Survey field activities in North Greenland commenced in 1974 with a four-man expedition to southern Peary Land. A $3000 \mathrm{~m}$ thick succession of Cambrian to Silurian carbonate and clastic sediments exposed in the Børglum Elv region was described but formal stratigraphy was not proposed (Peel \& Christie, 1975; Christie \& Peel, 1977).

In 1975 attention was turned to western North Greenland, where reconnaissance studies of the Lower Palaeozoic succession in Daugaard-Jensen Land (Henriksen \& Peel, 1976) were followed in 1976 and 1977 by similar studies in Washington Land and Inglefield Land. Standard profiles through the sequence were investigated as a preparation for the main phase of the North Greenland project (Peel, 1978, 1979; Hurst, 1980).

In 1975, a research project led by K. S. Dueholm (Institute of Surveying and Photogrammetry, Copenhagen) was initiated to investigate the coordination of topographical and photogeological interpretation, particularly in remote and essentially unmapped regions. The project was supported by GGU, with P. R. Dawes undertaking a primary study of Hall Land (Dawes, $1977,1987)$. The success of this venture was a major 
factor in influencing the establishment by GGU of a photogeological laboratory in 1978 (see below), with North Greenland as the first major region of study.

Detailed planning of the North Greenland Project progressed rapidly throughout the early 1970 s, with much discussion of the topographic map base of North Greenland and logistical problems. The defects of existing topographic maps were such that an entirely new topographic base map seemed essential (Lillestrand $e t$ al., 1968; Lillestrand \& Johnson, 1971). This eventually became possible with the enthusiastic support of the Geodetic Institute (GI; since 1988 part of Kort- og Matrikelstyrelsen, the National Survey and Cadastre) which led to the formulation of GGU/GI cooperation, combining geological and geodetic field work in North Greenland. Logistical problems were linked to the total dependency on air support for transportation of equipment, personnel, food and fuel supplies for aircraft. These necessitated negotiations with the military authorities of Denmark, the United States of America and Canada to permit use of the base facilities at Station Nord, Thule Air Base and Canadian Forces Station Alert, respectively. Practical details associated with base maps and logistics are discussed below.

The 1978-80 phase of field work during the North Greenland Project was carried out from a base camp at Fastelavnss $\emptyset$, a few kilometres north of Kap Harald Moltke in southern Peary Land (Fig. 5). The aim of the GGU work was to undertake regional geological investigations and field mapping throughout the area covered by the Peary Land map sheet (1:500 000 series, sheet 8; Fig. 2). However, field activities extended beyond this area in response to the scientific demands of the developing field work and as a result of reconnaissance activities prior to the second phase of the project (1984-85).

Participation by the Geodetic Institute was concentrated in the period $1978-80$, with the aim of establishing new survey ground control points throughout northern Greenland. This work was undertaken from three base camps, at Fastelavnss $\varnothing$ (shared in 1978 with GGU), Centrum $\$ \varnothing$ in Kronprins Christian Land, and in south-east Warming Land (Fig. 5). The new ground control points were to be used in conjunction with new aerial photographs taken in 1978 for the production of orthophotographic maps (see also below).

GGU field work in 1984-85 was carried out from the base in southern Warming Land, and extended throughout the ice-free land areas between Washington Land in the west to Nansen Land and Lauge Koch Land in the east; this corresponds approximately to the boundaries of the Nyeboe Land map sheet (1:500 000 map series, sheet 7; Fig. 2). A special element in this phase of the
North Greenland Project was cooperation with 'Projekt Nordolie', a GGU-manned enterprise financed by the Danish Ministry of Energy and aimed at the assessment of the hydrocarbon potential of the Lower Palaeozoic Franklinian Basin in North Greenland (Christiansen, 1989).

\section{Cartography and photogeology}

Lauge Koch's early field work was a major step forward in the surveying of northern Greenland, leading to the publication of a set of 19 map sheets at 1:300 000 by the Geodetic Institute (Koch, 1932). Koch used a theodolite for the measurement of angles, while astronomical determinations were measured by Zenith distances of the sun (Koch, 1922).

The first aerial surveys for the purpose of map making were carried out by the U.S. Air Force in 1947 and the resulting trimetrogon photography taken at $6000 \mathrm{~m}$ formed the basis of the 1:250 000 map series published in the 1950s by the U.S. Army Map Service (AMS) and the U.S.A.F. Aeronautical Chart and Information Center (ACIC). Both the ACIC and AMS map series covering northern Greenland are characterised by poor absolute map accuracy, mainly due to lack of a ground control net and reliance on the same astronomical position fixes incorporated into Koch's maps of 1932. The largest single error in absolute location is about $23 \mathrm{~km}$ and the highest proven map scale error about $20 \%$ (Lillestrand et al., 1968; Lillestrand \& Johnson, 1971). Information content is poor, and altitude errors of several hundred metres lead to poor representation of topographic features. For representation of detailed geological documentation the AMS and ACIC maps are thus a totally inadequate base.

When the North Greenland Project was being planned the AMS/ACIC 1:250 000 series provided the only map coverage for all of northern Greenland. Excellent 1:50000 maps prepared by the Geodetic Institute existed for a small area immediately around Jørgen Brønlund Fjord, and the same institute had also prepared 1:100 000 uncontoured photomosaics for much of Peary Land using 1:54 000 vertical aerial photographs taken in the period 1959-61. Much of GGU's early planning concerned assessment of the existing map coverage and evaluation of ways in which map material might be modified in order to produce an acceptable base map for geological documentation. An evaluation of photointerpretation techniques was made with a view to the construction of maps by untraditional methods (see discussion in Dawes, 1987).

These considerations led to formulation of the research project led by K. S. Dueholm (as noted above), 
aimed particularly at the coordination of topographical and geological mapping, and the development of methods for increased extraction of geological information from aerial photographs (Dueholm, 1979). Two GGU geologists were attached to the project, P. R. Dawes from 1975 with Hall Land as a study area (Dawes, 1977, 1987), and later H. F. Jepsen in the Washington Land area (Jepsen \& Dueholm, 1978). It was clear that most of North Greenland was well suited to photogeological interpretation, with vegetation being scarce and with large areas comprising well exposed and laterally continuous rock units.

The dilemma with respect to the inaccurate existing maps was resolved with formulation of the work in North Greenland as a joint venture with the Geodetic Institute (see above). As producing maps of North Greenland from the existing 1:54 000 vertical photographic coverage would require photogrammetric work on 8000 stereoscopic pairs of photographs, an almost insurmountable task, it was decided to undertake new super-wide angle aerial photography at a scale of
1:150 000 which would reduce the photogrammetric work to a more manageable 1300 pairs (Bengtsson, 1983). Ground control points were established throughout North Greenland in the summer seasons 1978-80 using a doppler satellite position system combined with barometric and triangulation measurements; this permitted a precision of $1 \mathrm{~m}$ in all three dimensions (Madsen, 1979; Bengtsson, 1983). A regional gravity network was established at the same time; preliminary Bouguer anomaly maps have been compiled (Forsberg, 1979, 1981; Weng, 1980) and a geoid prediction established (Forsberg \& Madsen, 1981).

The new aerial photographs were taken in 1978 from a Lear Jet $25 \mathrm{C}$ aircraft, operating out of Thule Air Base and from Svalbard. Flight altitude was $14 \mathrm{~km}$. A set of super-wide angle photographs was taken in black and white at $1: 150000$ with $40 \%$ lateral overlap and $80 \%$ overlap in the flight direction. A set of infrared, false colour, wide angle photographs was taken at 1:87 000 with $67 \%$ overlap in the flight direction, but without side overlap. On the basis of the 1:150 000 photographs and

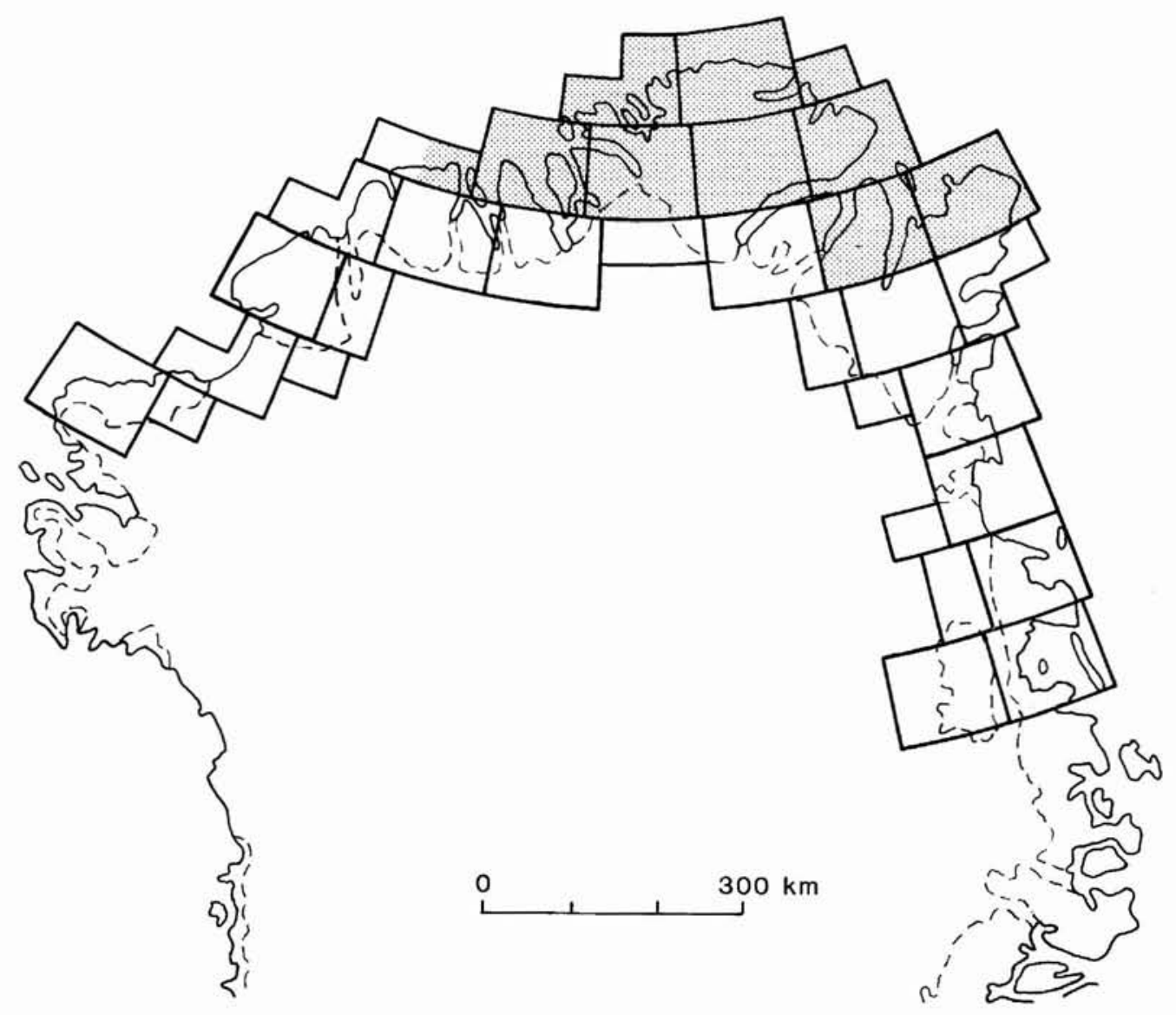

Fig. 6. Areas to be covered by 1:100 000 orthophotographic maps of North and North-East Greenland under preparation by Kortand Matrikelstyrelsen (formerly Geodetic Institute). Published map sheets are shown by shading. 


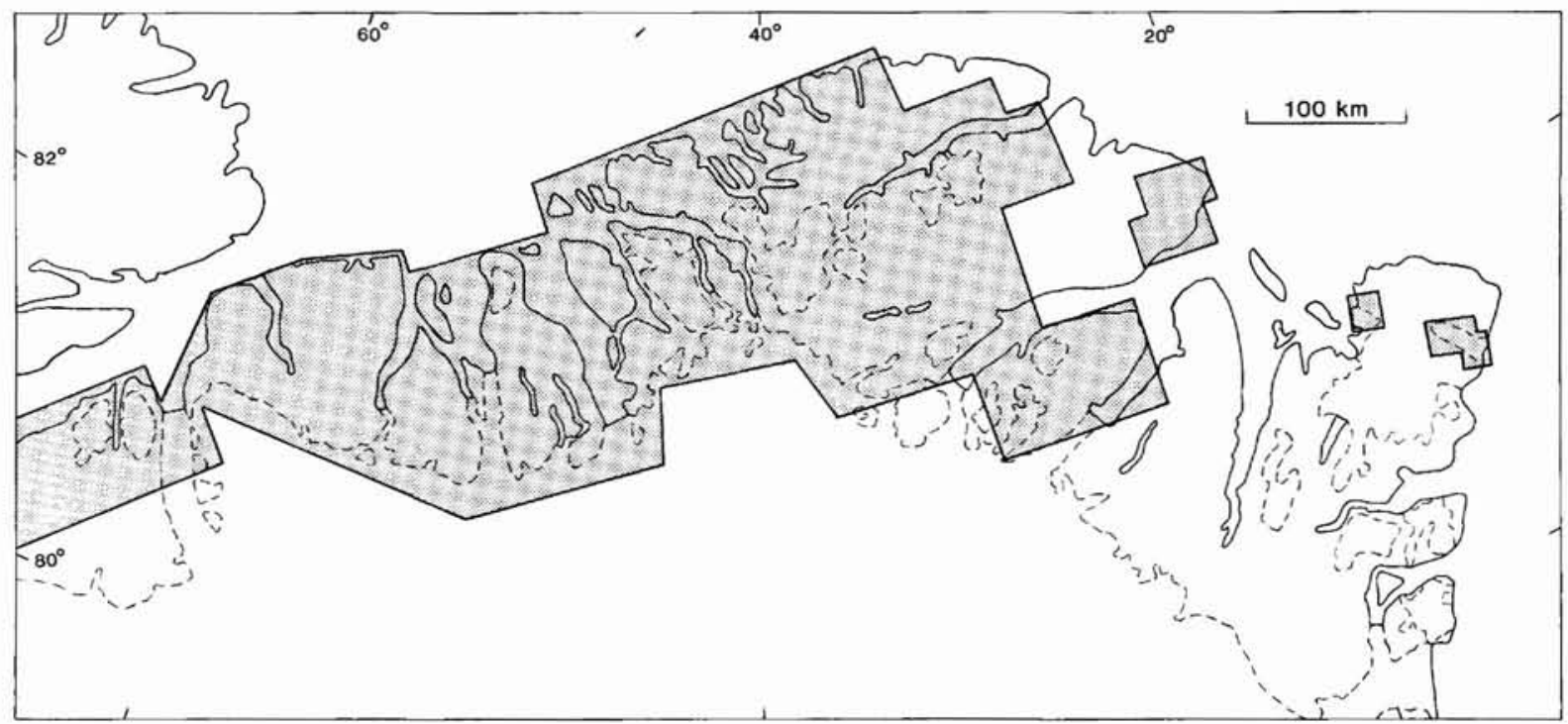

Fig. 7. North Greenland showing the areas (shaded) for which 1:100 000 topographical maps with a $100 \mathrm{~m}$ contour interval have been compiled by GGU using ground control data and aerial photographs supplied by the Geodetic Institute.

the new ground control points, new maps with $100 \mathrm{~m}$ contours were constructed, and publication by the Kortog Matrikelstyrelsen is in the form of 1:100 000 orthophotographic maps which will eventually cover not only North Greenland, but also North-East Greenland with a southern boundary at Bessel Fjord $\left(76^{\circ} \mathrm{N}\right.$; Fig. 6).

In the 1978 summer season geological observations were compiled mainly on individual 1:54 000 aerial photographs or 1:100 000 photomosaics, but from 1979 the new 1:150 000 photographs became available, as well as individual 1:100 000 orthophotographs. Subsequently new 1:100 000 topographic maps were used for compilation purposes, and these also provided the topographic base for published 1:100 000 and 1:500 000 geological map sheets.

In 1977 GGU purchased a Kern PG 2-D stereo-plotter and desk top calculator (Jepsen \& Dueholm, 1978). Methods for calculating geological parameters developed by Dueholm were elaborated. In due course expanded computer facilities were added and a semi-automatic drawing table was attached to the system. Programs permit calculation of dip and strike, fault displacements and bed thicknesses from precise photogrammetric measurements. Calculated dip and strike measurements can also be combined to calculate local fold axes, and it is possible to extrapolate precisely the course of bedrock geological boundaries into poorly exposed and covered areas (cf. Pedersen, 1981; Bengaard, 1989; Hougaard et al., 1991).

Photogeological studies using this instrumentation began with compilation of areas on both sides of Frederick E. Hyde Fjord (Pedersen, 1979, 1981, 1986), and later extended to other parts of Peary Land. A substantial part of the region was eventually interpreted photogeologically on a new 1:100 000 topographic base (Fig. 7). However, compilation of the 1978-80 geological field maps for the 1:500 000 Peary Land map (sheet 8) was carried out in a variety of ways, due to the overlap of field work, aerial photography, and photogeological interpretation. Some data were interpreted photogrammetrically, whereas other parts were transferred by hand from aerial photographs or photomosaics via orthophotographs to $1: 100000$ outline maps.

Preparations for the second phase of field work (1984-85) included photogeological interpretation using the Kern stereo-plotter of the entire region. Data was compiled on a total of 201:100 000 topographic maps prepared in GGU on the basis of GI control points. Field observations from the 1984-85 summers were compiled on the same topographic base. Final compilation of the 1:500 000 Nyeboe Land map sheet was based on a combination of 1:100 000 photogeological and geological field maps.

\section{Logistics}

Access to North Greenland is only practical by air. There are only four landing strips in the region usable by large transport aircraft, and three of these are natural landing strips (Pileheden in Hall Land, Kap Harald 


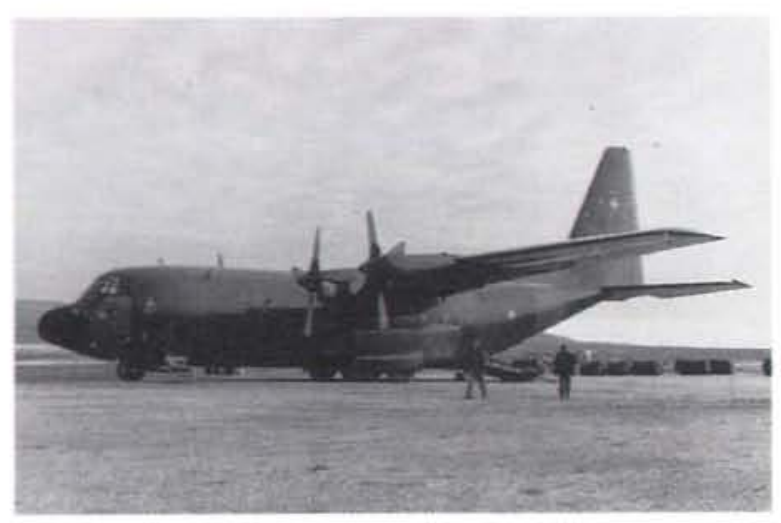

Fig. 8. Royal Danish Airforce C-130 transport aircraft on the natural landing strip at the Kap Moltke station, Kap Harald Moltke, Peary Land.

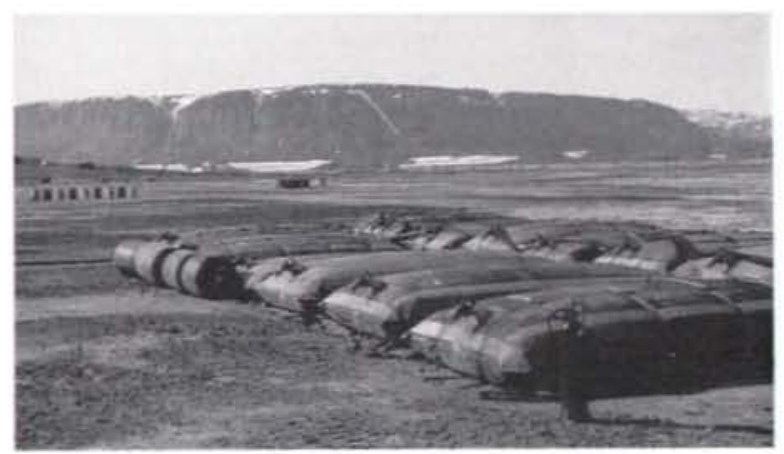

Fig. 9. Rubber bladder tanks for aviation fuel, each with a capacity of 35001 , at Kap Moltke.

Moltke and Centrum Sø) without any facilities (Fig. 5). The fourth strip, at Station Nord, is operated by military personnel but offers few facilities. Any large expeditionary activity must be self-supporting, an obligation which necessitated careful planning at GGU's home offices in Copenhagen. All personnel, equipment and aircraft fuel were flown in at the beginning of the field season, and at the end of the season personnel, equipment and rock samples were flown out.

The willingness of the Royal Danish Air Force (RDAF) to assist the expedition with their C-130 Hercules transport aircraft (Fig. 8) was a major factor in the success of the North Greenland project. With a mixed cargo of personnel, equipment, provisions and small helicopters, the payload of these aircraft to North Greenland destinations was 10-12 tons. During the first three years of the project (1978-80) the expedition and its equipment were transported to and from Station Nord in one or two flights from Denmark. Bulk transport of aviation fuel was carried out with RDAF C-130 aircraft equipped with special tank equipment, in coordination with the annual resupply of Station Nord in May. A total of 100000 I of jet fuel (JP-4) was purchased from U.S. military authorities at Thule Air Base each season and flown to Kap Harald Moltke (Fig. 9), where it was stored in large rubber bladder tanks, each with a capacity of $3500 \mathrm{I}$.

During the second phase of field work (1984-85) the Canadian Forces Station Alert in north-east Ellesmere Island was used as a transit and support base for the expedition. RDAF C-130 aircraft transported the expedition into and out of Alert, and were also used to air lift the expedition's fuel from Thule Air Base to Alert where it was stored in permanent fuel storage tanks until needed. The expedition's Twin Otter fixed-wing aircraft made regular flights from Alert to the field base camp in Greenland with a cargo of $1200-15001$ of fuel, mainly for helicopter use.

Transport of field parties within North Greenland was mainly by helicopter and, in each of the five seasons, two Bell 206 Jet Ranger helicopters were chartered by GGU. In 1979 and 1980, when the Geodetic Institute operated from their own base camp, an additional helicopter was chartered. The helicopters were operated with fixed flotation gear and, with a payload of $350-380$ kg, could each transport a 2-person standard camp (Fig. 10). The two helicopters logged a total of $400-500$ flying hours each season in North Greenland.

A Twin Otter aircraft with STOL (Short Take-off and Landing) capabilities and equipped with tundra tyres was chartered each season, and used mainly for transport of personnel, equipment, provisions and fuel from the C-130 airstrips to the base camp sites (Fig. 11). Its ability to operate from unprepared landing sites was widely exploited, notably for establishment of fuel de-

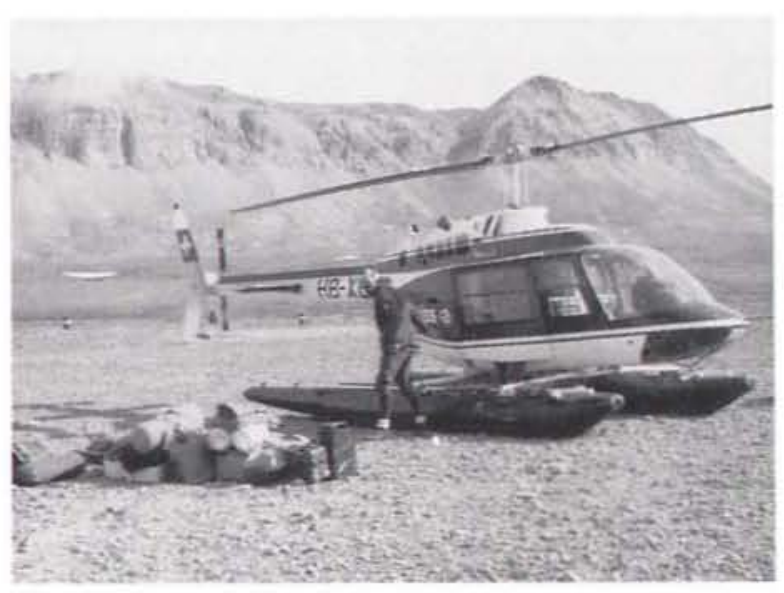

Fig. 10. Bell 206 Jet Ranger helicopter with equipment for a two-man geological field camp being loaded. 


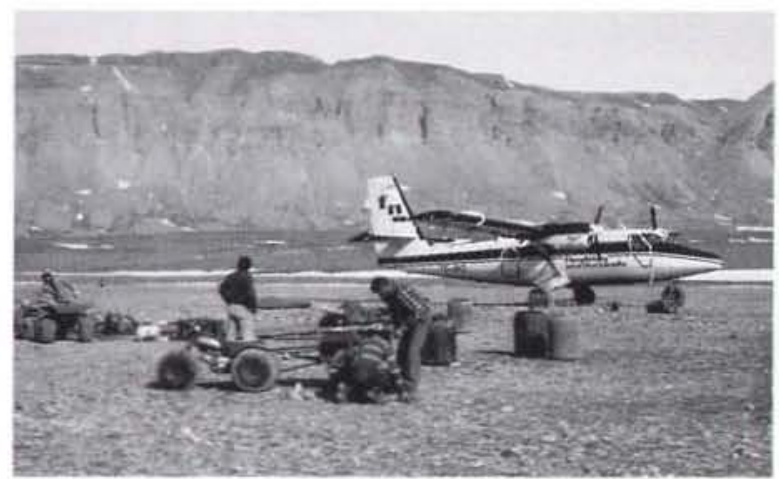

Fig. 11. De Havilland Twin Otter aircraft on the gravel terrace airstrip at the Fastelavnsss base camp. In the foreground allterrain motor tricycles used for local transport, and several 55 gallon $(200 \mathrm{I})$ reusable rubber drums of aviation fuel.

pots for use by the helicopters. More than 30 landing sites were established (cf. Fig. 5), few of which required more than a few hours of levelling with shovel and spade to be acceptable. The Twin Otter proved also to be ideal for low-level photographic flights, which were made along nearly all major fjords and valleys (Fig. 12). Black and white and colour photographs of the well exposed cliff sections have provided a considerable amount of geological information.

Nearly all geological field work was carried out by two-man teams. These usually comprised two geologists working together, often with different specialities, so that the various aspects of the geology could be more effectively studied. Field teams lived throughout the season in small tent camps. For the most part field camps were moved by helicopter $25-50 \mathrm{~km}$ at 5-7 day intervals; camp moves were often combined with helicopter reconnaissance so that geological mapping could be extended over larger areas. Each team had 8-12 camp positions each season (Fig. 13).

Base camps were established each year on locations known to be free of snow early in the season (Fig. 5). The base camp was the operational centre for the expedition, and comprised about 20 small living tents, three or four large $\left(20 \mathrm{~m}^{2}\right)$ storage tents, an Atwell hut (30 $\mathrm{m}^{2}$ ) for kitchen and canteen use and a small radio hut (Fig. 14). There was also a complete system for fuel storage and refuelling of aircraft. The base camp had a normal permanent staff of four; other residents usually included the expedition leader and aircraft pilots and mechanics, while members of field parties were occasional guests.

Communication between the base camp and aircraft and field camps was maintained using HF-SSB radios and frequencies in the $3000-5500 \mathrm{khz}$ range. Despite the limited transmitter power of the field radios (5-10 watts) radio communication was generally very reliable, mainly because of the low radio noise level in the Arctic. During aircraft operations regular reports were made to base camp at 10-20 minute intervals, with positions indicated with reference to a $10 \times 10 \mathrm{~km}$ UTM grid. The base camp radio, with a transmitter power of 100 watts, enabled regular connections to be made with other main stations in the region, as well as with the

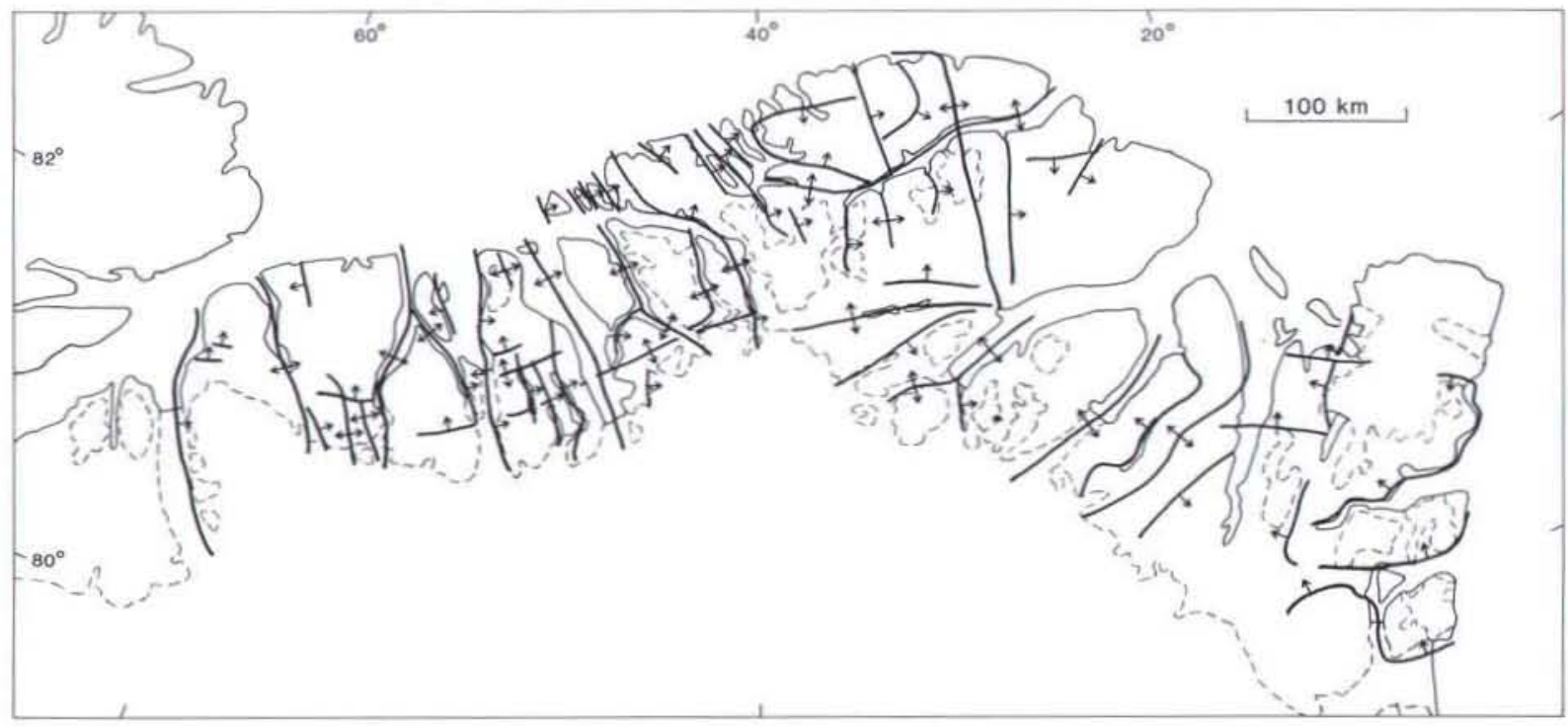

Fig. 12. Index map showing the routes of photographic flights made with the Twin Otter during the project. Black and white photographs and colour transparencies were taken of most steep-sided fjords and valleys. 


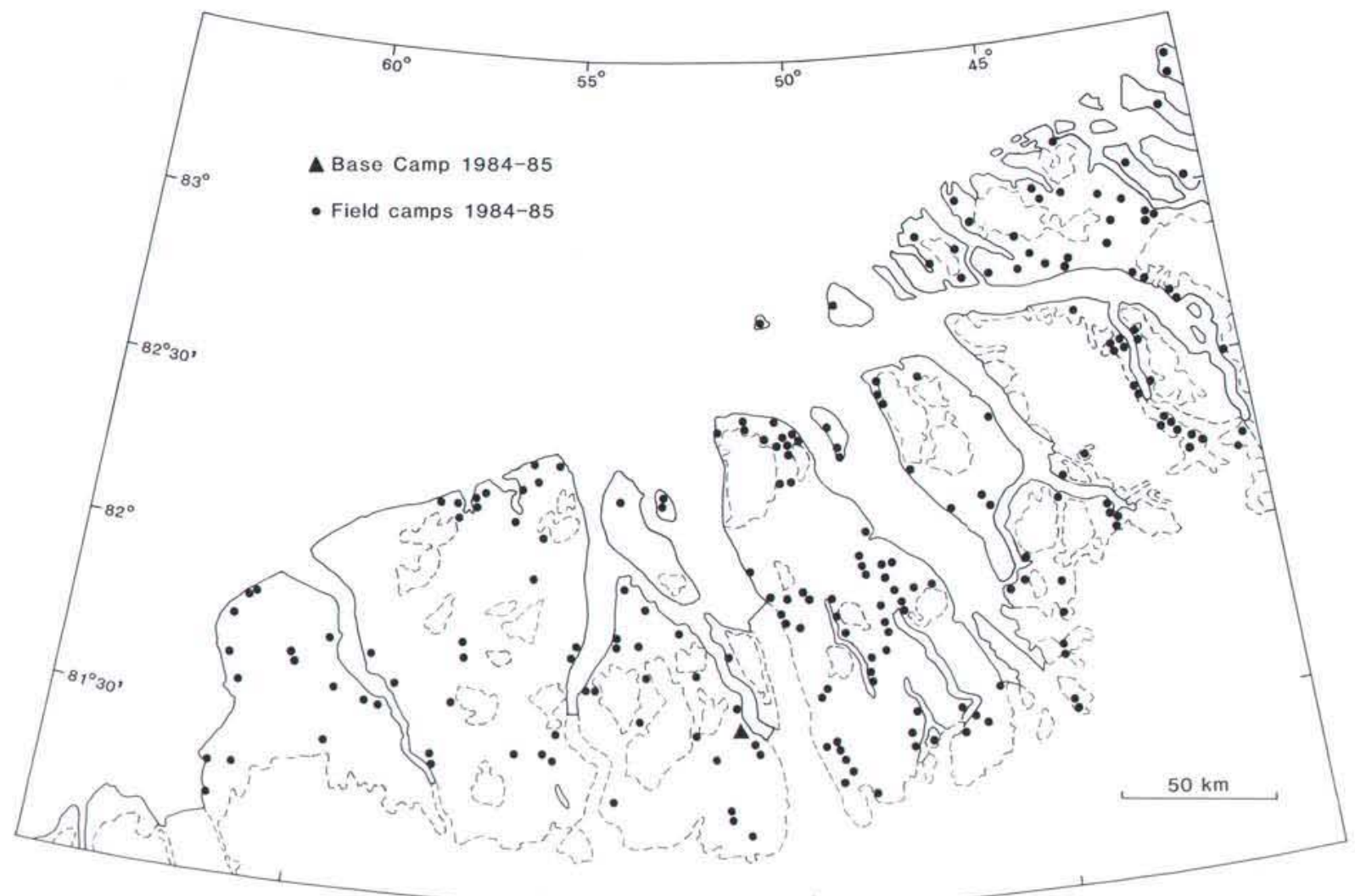

Fig. 13. Distribution of field party camp sites in the region of the 1:500 000 Nyeboe Land sheet (sheet 7) during the 1984-85 field seasons.

outside world via Danmarkshavn weather station and Thule Air Base.

The vulnerability of the Arctic environment and the inclusion of all of the working region within the NorthEast Greenland National Park placed a particular obligation on field parties and base camp personnel to cause
Fig. 14. Base camp on river terraces in south-eastern Warming Land, looking east towards Permin Land, with helicopters and the Twin Otter in the foreground. The camp comprises four large tents for equipment, radio and kitchen huts, and about 20 small tents for personnel.

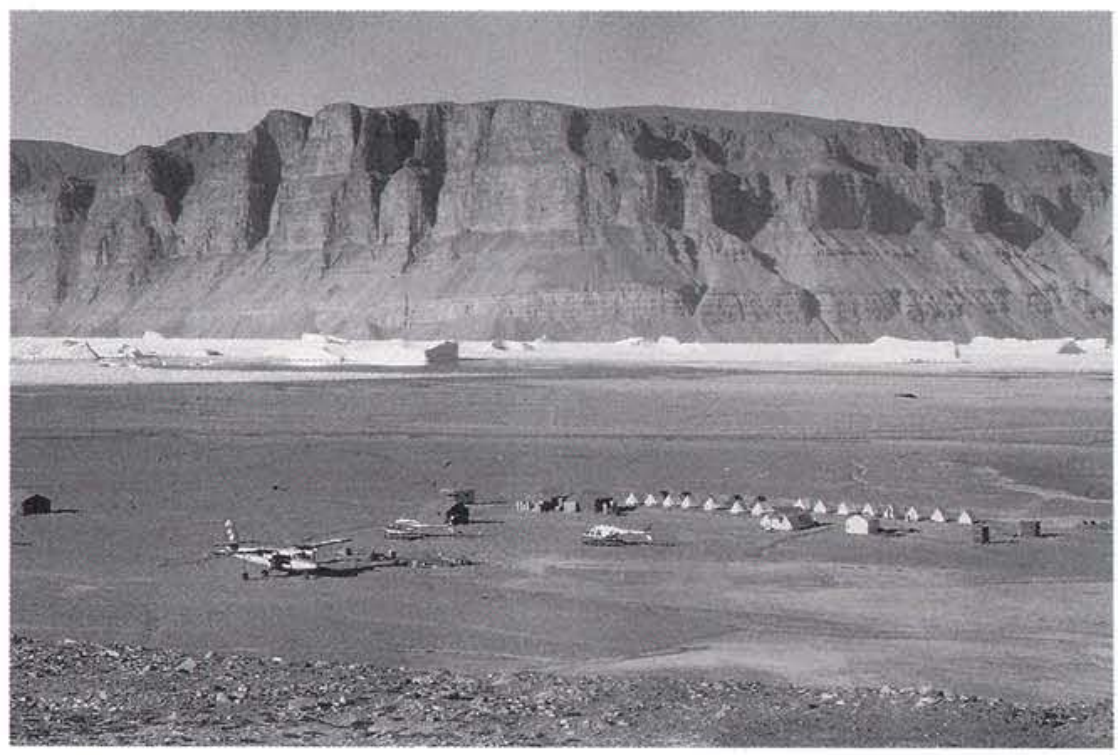


as little disturbance as possible to the original conditions in their camp site vicinity. This applied particularly to the disposal of kitchen rubbish, which ideally was returned to base camp. The problem of disposal of metal fuel drums was avoided by use of rubber bladder tanks for main fuel storage, and 55 gallon (c. $200 \mathrm{l}$ ) reusable rubber drums (Fig. 11) for small fuel depots established by Twin Otter or helicopter. At the termination of the project, base camp sites were completely cleared, and no depots or huts remain.

\section{Scientific cooperation}

The close cooperation with the Geodetic Institute was, as noted above, a vital factor in resolving the problem of the poor quality of existing topographic maps. The formulation of the $1978-80$ phase of field work as a joint GGU/GI project also added an important element of security, in that it became financially viable to operate with at least two helicopters each season. In the second phase of the project (1984-85) the same degree of security was achieved when the pet- roleum source rock programme 'Projekt Nordolie' financed by the Danish Ministry of Energy was fully integrated with the GGU work (Christiansen, 1989). Groups from the Greenland Technical Organisation and Greenland Fisheries and Environmental Research Institute also took part in the second phase of the project, carrying out a variety of technical, environmental and biological investigations (Grønlands Fiskeri- og Miljøundersøgelser, 1986).

Between 15 and 23 geologists participated in each of the 5 years of the project. Of these, 8 geologists took part for between 3 and 5 seasons each. The field geologists included 16 from GGU, 17 from Danish universities, and 20 from geological institutes outside Denmark. A particularly rewarding aspect of the geological work has been the number of $\mathrm{Ph} . \mathrm{D}$. or similar research studies which have been undertaken at Danish and foreign institutes. Pedersen (1982) and Bennike (1989) completed lic. scient. (= Ph.D.) studies at the University of Copenhagen. Three Ph.D. studies at the University of Nottingham, U.K., funded by the National Environmental Research Council (NERC) have pro-

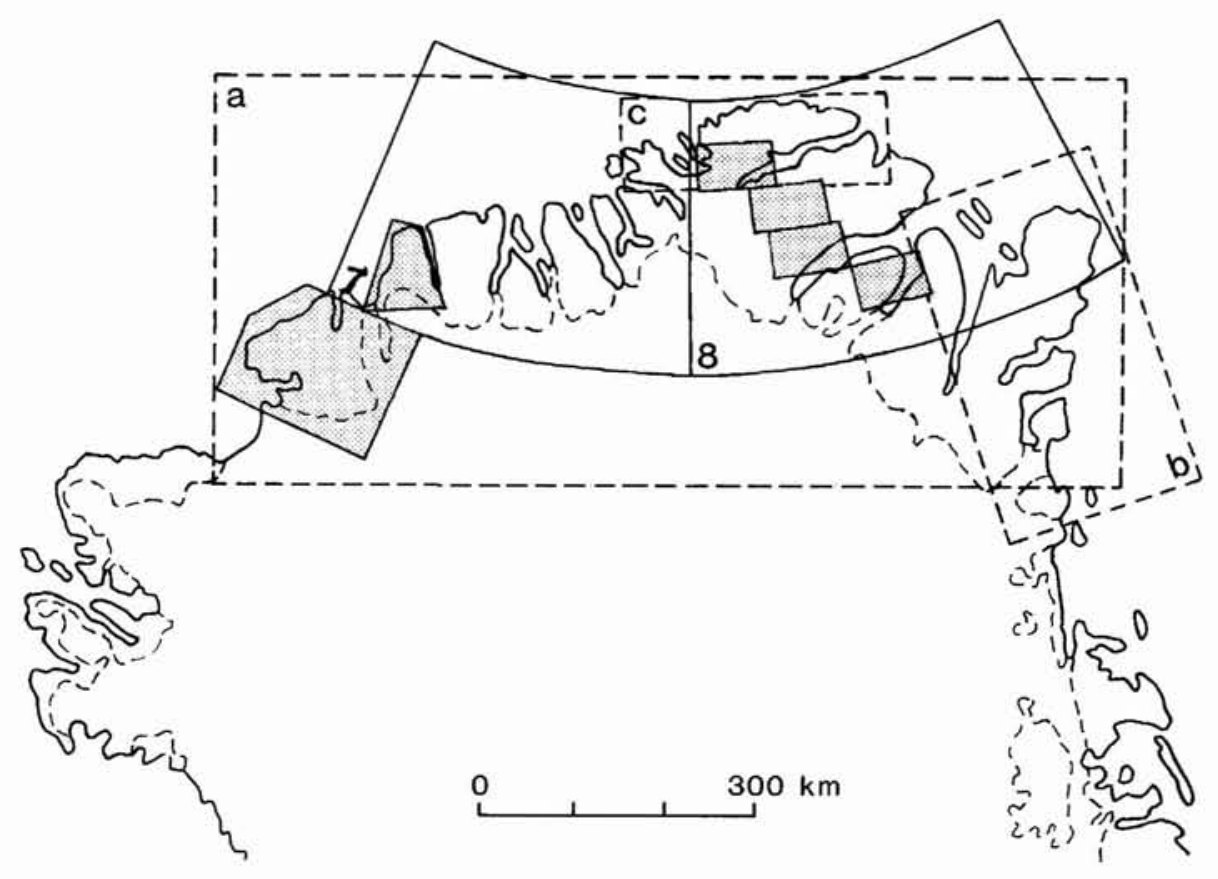

Published maps

Full line boundaries: Coloured maps

Dashed line boundaries: Black \& white maps

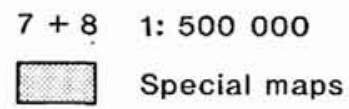

$$
a+b \quad \text { 1: } 1000000
$$$$
\text { c 1: } 500000
$$

Fig. 15. Published geological maps resulting from the North Greenland Project and associated activities. 
vided a biostratigraphic framework for much of the carbonate platform sequence (Armstrong, 1983, 1990; Smith, 1985, in press; Tull, 1988). Ph.D. projects at the Universities of Keele, U.K., and Kansas, U.S.A., studied aspects of Cambrian basin evolution and biostratigraphy (Ineson, 1985; Babcock, 1990; M. R. Blaker, in preparation at Keele University).

\section{Scientific results}

GGU has published two 1:500 000 geological map sheets (sheet 7, Nyeboe Land; sheet 8, Peary Land) and four 1:100 000 geological maps forming a NW-SE transect from J. C. Christensen Land to Peary Land (Fig. 15). Coloured geological maps of Washington Land (1:250 000, printed 1983) and Hall Land (1:66 500; Dawes, 1987) have also been published. A black and white geological map of North Greenland (1:1 000000$)$ published in 1987 (Rapp. Grønlands geol. Unders. 133) is reproduced herein with minor modifications as Map 1. A compilation at a scale of 1:1000 000 of the Kronprins Christian Land area accompanied Rapp. Grønlands geol. Unders 106, together with a 1:500 000 geological map of Johannes V. Jensen Land. A preliminary map of the area from J. P. Koch Fjord to Danmark Fjord accompanied Rapp. Grønlands geol. Unders $\mathbf{8 8}$. One of two maps of Quaternary geology at a scale of 1:1 000000 planned to cover the same area as the Nyeboe Land and Peary Land map sheets has been printed (Bennike \& Kelly, 1990).

Reference to many of the publications arising from the North Greenland Project is made in the respective papers which make up this bulletin. These are mainly in respect of the stratigraphical, sedimentological and palaeontological aspects of the sedimentary basin studies.

Other published studies include: Precambrian crystalline basement at the head of Victoria Fjord (Henriksen \& Jepsen, 1985); structural studies in the North Greenland fold belt (Bengaard et al., 1987; Friderichsen \& Bengaard, 1985; Higgins et al., 1985; Pedersen, 1986; Soper et al., 1980; Soper \& Higgins, 1990; structural studies in the northern part of the Caledonian fold belt (Hurst \& McKerrow, 1985; Hurst et al., 1985; Jepsen \& Kalsbeek, 1985); geochronological studies (Hansen et al., 1987; Kalsbeek \& Jepsen, 1983; Larsen \& GraffPetersen, 1980; Springer, 1981); studies of Tertiary volcanics (Brown et al., 1987); Quaternary geology (Funder \& Hjort, 1980; Bennike \& Kelly, 1990); geomagnetic and palaeomagnetic investigations (Abrahamsen \& Marcussen, 1980; Abrahamsen \& Van der Voo, 1987a, b; Marcussen \& Abrahamsen, 1983); geochemical exploration reconnaissance (Ghisler \& Stendal, 1980; Jakobsen \& Stendal, 1987; Steenfelt, 1980, 1985, 1987).
Research on rock and fossil collections continues, both at GGU and in collaboration with outside institutes (e.g. Peel, 1988). In some cases supplementary field work has been carried out in North Greenland, funded by the Carlsberg Foundation, Copenhagen. Thus, additional field studies were made of the Pliocene-Pleistocene Kap København Formation in 1984 (Bennike, 1989), in the Wandel Sea Basin sequence around Station Nord and at Kilen in 1985 (Håkansson \& Stemmerik, 1989, in press; Håkansson et al., in press), and new collections of a soft-bodied Burgess Shale type fauna were made from near J. P. Koch Fjord in 1989 (Conway Morris et al., 1987, 1990; Peel, 1990). Field work mainly supported by external sources is scheduled to continue in 1991 in the Wandel Sea Basin sequence of eastern Peary Land and the J. P. Koch Fjord area.

Acknowledgements. It is not possible to acknowledge all the individuals, companies and institutions who have contributed to the successful conclusion of the North Greenland Project. However, mention must be made of the Royal Danish Air Force and the crews of the C-130 aircraft who carried the expedition to and from Greenland. The Swiss company Heliswiss A. G. of Berne, who have 20 years experience of charter operations for GGU in Greenland, and the Icelandic Company Flugfélag Norðurlands of Akureyri who carried out Twin Otter operations, also deserve special mention. Canadian and U.S. military authorities are acknowledged for their permission to use military facilities at Alert and Thule Air Base, respectively.

Eigil Knuth, leader of the Danish Peary Land expeditions provided a great deal of help in the planning stage of the project, and use was made of the natural airstrip established and maintained by Knuth at Kap Harald Moltke. Danish military personnel at Station Nord were most helpful during the first phase of the project (1978-80). Danish military authorities also gave permission for the use of huts established by the Sirius Sledge Patrol in North Greenland.

Ulla Johansen, Grethe Hougaard and Jakob Lautrup are thanked for technical assistance in the preparation of this manuscript which was reviewed by Peter R. Dawes and John S. Peel.

\section{References}

Abrahamsen, N. \& Marcussen, C. 1980: Preliminary results of rock- and palaeomagnetic fieldwork in Peary Land, North Greenland. Rapp. Grønlands geol. Unders. 99, 137-145.

Abrahamsen, N. \& Van der Voo, R. 1987a: Magnetic susceptibility and palaeomagnetic collection of rocks from central and western North Greenland. Rapp. Gronlands geol. Unders. 133, 133-139.

Abrahamsen, N. \& Van der Voo, R. 1987b: Palaeomagnetism of middle Proterozoic (c. $1.25 \mathrm{Ga}$ ) dykes from central North Greenland. Geophys. J. R. astr. Soc. 91, 597-611. 
Armstrong, H. A. 1983: The Early Silurian conodont micropalacontology of the North Greenland carbonate platform. Unpublished Ph.D. thesis, Univ. Nottingham, U.K., 387 pp.

Armstrong, H. A. 1990: Conodonts from the Upper Ordovician - Lower Silurian carbonate platform of North Greenland. Bull. Grønlands geol. Unders. 159, $151 \mathrm{pp}$.

Babcock, L. E. 1990: Biogeography, phylogenetics, and systematics of some Middle Cambrian polymeroid trilobites from open-shelf to basinal lithofacies of North Greenland and Nevada. Unpublished Ph.D. thesis, Univ. Kansas, U.S.A., 222 pp.

Bengaard, H.-J. 1989: Geometrical and geological analysis of photogrammetrically measured deformed sediments of the fjord zone, central East Greenland. Open File Ser. Grønlands geol. Unders. 89/6, 101 pp.

Bengaard, H.-J., Davis, N. C., Friderichsen, J. D. \& Higgins, A. K. 1987: Lithostratigraphy and structure of the North Greenland fold belt in Nansen Land. Rapp. Grønlands geol. Unders. 133, 99-106.

Bengtsson, T. 1983: The mapping of northern Greenland. Photogram. Rec. 11(62), 135-150.

Bennike, O. 1984: Sen-Kænozoiske sedimenter fra Kap København, østlige Nordgrønland: sedimentologi og palæobiologi. Unpubl. cand. scient. thesis, Univ. Copenhagen, 172 pp.

Bennike, O. 1990: The Kap København Formation: stratigraphy and palaeobotany of a Plio-Pleistocene sequence in Peary Land, North Greenland. Meddr Grønland Geosci. 23, 85 pp.

Bennike, O. \& Kelly, M. 1990: Quaternary map of the Hall Land - Nansen Land region, North Greenland, 1:1 000000. Copenhagen: Grønlands geol. Unders.

Brown, P. E., Parsons, I. \& Becker, S. M. 1987: Peralkaline volcanicity in the Arctic Basin - the Kap Washington Volcanics, petrology and palaeotectonics. J. geol. Soc. Lond. 144, 707-715.

Christiansen, F. G. (ed.) 1989: Petroleum geology of North Greenland. Bull. Grønlands geol. Unders. 158, 104 pp.

Christie, R. L. \& Dawes, P. R. in press: A history of exploration and geology in the Innuitian region. In Trettin, H. P. (ed.) Innuitian orogen and Arctic Platform: Canada and Greenland. Geology of Canada 3. Ottawa: Geol. Surv. Can. (also The geology of North America E, Boulder, Colorado: Geol. Soc. Am.).

Christie, R. L. \& Peel, J. S. 1977: Cambrian-Silurian stratigraphy of Børglum Elv, Peary Land, eastern North Greenland. Rapp. Grønlands geol. Unders. 82, 48 pp.

Conway Morris, S. \& Peel, J. S. 1990: Articulated halkieriids from the Lower Cambrian of North Greenland. Nature 345, 802-805.

Conway Morris, S., Peel, J. S., Higgins, A. K., Soper, N. J. \& Davis, N. C. 1987: A Burgess shale-like fauna from the Lower Cambrian of North Greenland. Nature 326, 181-183.

Davies, W. E., Needleman, S. M. \& Klick, D. W. 1959: Report on Operation Groundhog (1958) North Greenland. Investigations of ice-free sites for aircraft landings, Polaris Promontory, North Greenland, 45 pp. Bedford: U.S.A.F. Cambridge Res. Center.
Davies, W. E., Krinsley, D. B. \& Nicol, A. H. 1963: Geology of the North Star Bugt area, Northwest Greenland. Meddr Grønland 162(12), 68 pp.

Dawes, P. R. 1971: The North Greenland fold belt and environs. Bull. geol. Soc. Denmark 20, 197-239.

Dawes, P. R. 1973: The North Greenland fold belt: a clue to the history of the Arctic Ocean Basin and the Nares Strait lineament. In Tarling, D. H. \& Runcorn, S. K. (ed.) Implications of continental drift to the earth sciences 2, 925-947. London \& New York: Academic Press.

Dawes, P. R. 1976: Precambrian to Tertiary of northern Greenland. In Watt, W. S. \& Escher, A. (ed.) Geology of Greenland, 248-303. Copenhagen: Geol. Surv. Greenland.

Dawes, P. R. 1977: Geological photo-interpretation of Hall Land: part of the regional topographical-geological mapping of northern Greenland. Rapp. Grønlands geol. Unders. 85, 25-30.

Dawes, P. R. 1984: Operation Grant Land 1965-1966; a geological exploration programme in Ellesmere Island and North Greenland. Rapp. Grønlands geol. Unders. 121, 5-17.

Dawes, P. R. 1987: Topographical and geological maps of Hall Land, North Greenland. Description of a computer-supported photogrammetrical research programme for production of new maps, and the Lower Palaeozoic and surficial geology. Bull. Grønlands geol. Unders. $155,88 \mathrm{pp}$.

Dawes, P. R. 1990: The North Greenland Continental Margin. In Grantz, A., Johnson, G. L. \& Sweeney, J. F. (ed.) The Arctic Ocean region. The geology of North America L, 211226. Boulder, Colorado: Geol. Soc. Am.

Dawes, P. R. \& Christie, R. L. 1982: History of exploration and geology in the Nares Strait region. In Dawes, P. R. \& Kerr, J. W. (ed.) Nares Strait and the drift of Greenland: a conflict in plate tectonics. Meddr Grønland Geosci. 8, 19-36.

Dawes, P. R. \& Haller, J. 1979: Historical aspects in the geological investigation of northern Greenland. Part 1: New maps and photographs from the 2nd Thule Expedition 19161918 and the Bicentenary Jubilee Expedition 1920-1923. Meddr Grønland 200(4), 38 pp.

Dawes, P. R. \& Peel, J. S. 1984: Biostratigraphic reconnaissance in the Lower Palaeozoic of western North Greenland. Rapp. Grønlands geol. Unders. 121, 19-51.

Dawes, P. R. \& Soper, N. J. 1973: Pre-Quaternary history of North Greenland. In Pitcher, M. G. (ed.) Arctic geology. Mem. Am. Ass. Petrol. Geol. 19, 117-134.

Dueholm, K. S. 1979: Geological and topographical mapping from aerial photographs. Meddr Inst. Surv. Photogramm. Danm. Tekn. Højsk. 10, 9-146.

Forsberg, R. 1979: A gravity map of Peary Land, North Greenland. Rapp. Grønlands geol. Unders. 88, 93-94.

Forsberg, R. 1981: Preliminary Bouguer anomalies of NorthEast Greenland. Rapp. Grønlands geol. Unders. 106, 105107.

Forsberg, R. \& Madsen, F. 1981: Geoid prediction in northern Greenland using collocation and digital terrain models. Ann. Geophys. 37,1, 31-36.

Friderichsen, J. D. \& Bengaard, H.-J. 1985: The North Greenland fold belt in eastern Nansen Land. Rapp. Grønlands geol. Unders. 126, 69-78. 
Funder, S. \& Hjort, C. 1980: A reconnaissance of the Quaternary of eastern North Greenland. Rapp. Gronlands geol. Unders. 99, 99-105.

Ghisler, M. \& Stendal, H. 1980: Geochemical and ore microscopic investigations on drainage sands from the Peary Land region, North Greenland. Rapp. Grønlands geol. Unders. 99, 121-128.

Grønlands Fiskeri- og Miljøundersøgelser 1986: Biologiske miljøundersøgelser i Nordgrønland 198485 . Unpubl. report, $113 \mathrm{pp}$.

Håkansson, E. \& Stemmerik, L. 1989: Wandel Sea Basin - a new synthesis of the Late Palaeozoic to Tertiary accumulation in North Greenland. Geology 17, 683686.

Håkansson, E., Birkelund, T., Heinberg, C., Hjort, C., Mølgaard, P. \& Pedersen, S. A. S. in press: The Kilen Expedition 1985 - a first account of geological and biological results. Bull. geol. Soc. Denmark.

Hansen, B. T., Kalsbeek, F. \& Holm, P. M. 1987: Archaean age and Proterozoic metamorphic overprinting of the crystalline basement at Victoria Fjord, North Greenland. Rapp. Grønlands geol. Unders. 133, 159-168.

Henriksen, N. \& Jepsen, H. F. 1985: Precambrian crystalline basement at the head of Victoria Fjord, North Greenland. Rapp. Gronlands geol. Unders. 126, 11-16.

Henriksen, N. \& Peel. J. S. 1976: Cambrian - Early Ordovician stratigraphy in south-western Washington Land, western North Greenland. Rapp. Grønlands geol. Unders. 80, 17-23.

Higgins, A. K. 1988: Glacier velocities from aerial photographs in North and North-East Greenland. Rapp. Grønlands geol. Unders. 140, 102-105.

Higgins, A. K., Soper, N. J. \& Friderichsen, J. D. 1985: North Greenland fold belt in eastern North Greenland. In Gee, D. G. \& Sturt, B. A. (ed.) The Caledonide Orogen: Scandinavia and related areas, 1017-1029. New York: John Wiley \& Sons.

Hougaard, G., Jepsen, H. F. \& Neve, J. K. 1991: GGU's photogeological laboratory: aerial photogrammetry - a valuable geological mapping tool in Greenland. Rapp. Grønlands geol. Unders. 152, 29-32.

Hurst, J. M. 1980: Silurian stratigraphy and facies distribution in Washington Land and western Hall Land, North Greenland. Bull. Grønlands geol. Unders. 138, 95 pp.

Hurst, J. M. \& McKerrow, W. S. 1985: Origin of the Caledonian nappes of eastern North Greenland. In Gee, D. G. \& Sturt, B. A. (ed.) The Caledonide Orogen-Scandinavia and related areas, 1065-1069. New York: John Wiley \& Sons.

Hurst, J. M. \& Jepsen, H. F., Kalsbeek, F., McKerrow, W. S. \& Peel, J. S. 1985: The geology of the northern extremity of the East Greenland Caledonides. In Gee, D. G. \& Sturt, B. A. (ed.) The Caledonide Orogen - Scandinavia and related areas, 1047-1063. New York: John Wiley \& Sons.

Ineson, J. R. 1985: The stratigraphy and sedimentology of the Brønlund Fjord and Tavsens Iskappe Groups (Cambrian) of Peary Land, eastern North Greenland. Unpublished Ph.D. thesis, Univ. Keele, U.K., 310 pp.

Jakobsen, U. H. \& Stendal, H. 1987: Geochemical exploration in central and western North Greenland. Rapp. Grønlands geol. Unders. 133, 113-121.

Jepsen, H. F. \& Dueholm, K. S. 1978: Computer supported geological photo-interpretation. Rapp. Gronlands geol. Unders. 90, 146-150.

Jepsen, H. F. \& Kalsbeek, F. 1985: Evidence for non-existence of a Carolinidian fold belt in eastern North Greenland. In Gee, D. G. \& Sturt, B. A. (ed.) The Caledonide Orogen Scandinavia and related areas, 1071-1076. New York: John Wiley \& Sons.

Kalsbeek, F \& Jepsen, H. F. 1983: The Midsommersø Dolerites and associated intrusions in the Proterozoic of eastern North Greenland - a study of the interaction between intrusive basin magma and sialic crust. J. Petrol. 24, 605-654.

Kelly, M. \& Bennike, O. 1985: Quaternary geology of parts of central and western North Greenland: a preliminary account. Rapp. Grønlands geol. Unders. 126, 111-116.

Koch, L. 1922: Note to maps of Melville Bay from Wilcox Point to Cape York and of North Greenland from $81^{\circ}-$ $83^{\circ} 35^{\prime} \mathrm{N}$, to $38-56^{\circ} \mathrm{W}$. Meddr Grønland $65(2), 77-88$.

Koch, L. 1925: The geology of North Greenland. Am. J. Sci. 9, 271-285.

Koch, L. 1926: Report on the Danish Bicentenary Jubilee Expedition north of Greenland 1920-23. Meddr Grønland 70,1(1), 1-232.

Koch, L. 1929: Stratigraphy of Greenland. Meddr Grønland 73,2(2), 205-320.

Koch, L. 1932: Map of North Greenland, scale 1:300 000, surveyed by Lauge Koch in the years 1917-23, 18 sheets. Copenhagen: Geodetic Inst.

Larsen, O. \& Graff-Petersen, P. 1980: Sr-isotope studies and mineral composition of the Hagen Bræ Member in the Proterozoic clastic sediments at Hagen Bræ, eastern North Greenland. Rapp. Grønlands geol. Unders. 99, 111-118.

Madsen, F. 1979: Application of doppler technique in Greenland for Geodetic Control. 2nd Internat. Geodetic Symposium on Satellite Doppler Positioning, 989-999. Austin, Texas.

Marcussen, C. \& Abrahamsen, N. 1983: Palaeomagnetism of the Proterozoic Zig-Zag Dal Basalt and the Midsommers $\emptyset$ Dolerites, eastern North Greenland. Geophys. J. R. astr. Soc. 73, 367-387.

Pedersen, S. A. S. 1979: Photogrammetric/geological mapping compared with field geological mapping of the area Freja Fjord, central Peary Land, North Greenland. Meddr Inst. Surv. Photogramm. Danm. Tekn. Højsk. 10, 174-181.

Pedersen, S. A. S. 1981: The application of computer-assisted photogrammetric methods in the structural analysis of part of the North Greenland Fold Belt. J. struct. Geol. 3, 253264.

Pedersen, S. A. S. 1982: Structural analysis of the southern margin of the North Greenland fold belt in Peary Land. Unpubl. lic. scient. thesis, Univ. Copenhagen, 230 pp.

Pedersen, S. A. S. 1986: A transverse, thin-skinned, thrustfault belt in the Paleozoic North Greenland Fold Belt. Bull. geol. Soc. Am. 97, 1442-1455.

Peel. J. S. 1977: Cambrian-Silurian studies in Washington 
Land, western North Greenland. Rapp. Grønlands geol. Unders. 85, 30-33.

Peel, J. S. 1978: Geological investigations in Lower Palacozoic terrain of northern Greenland between $78^{\circ} 30^{\prime} \mathrm{N}$ and $81^{\circ} 30^{\prime} \mathrm{N}$. Rapp. Grønlands geol. Unders. 90, 14-16.

Peel, J. S. 1979: Revision of Ordovician-Silurian gastropods from North Greenland. Rapp. Grønlands geol. Unders. 91, 61-70.

Peel, J. S. (ed.) 1988: Stratigraphy and palaeontology of the Holm Dal Formation (late Middle Cambrian), central North Greenland. Meddr Grønland Geosci. 20, 168 pp.

Peel, J. S. 1990: Studying the early history of life in Greenland. Rapp. Grønlands geol Unders. 148, 54-56.

Peel, J. S. \& Christie, R. L. 1975: Lower Palaeozoic stratigraphy of southern Peary Land, eastern North Greenland. Rapp. Grønlands geol. Unders. 75, 21-25.

Smith, M. P. 1985: Ibexian-Whiterockian (Ordovician) conodont palaeontology of East and eastern North Greenland. Unpublished Ph.D. thesis, Univ. Nottingham, U.K., 364 pp. Smith, M. P. in press: Early Ordovician conodonts of East and North Greenland. Meddr Grønland Geosci.

Soper, N. J. \& Higgins, A. K. 1990: Models for the Ellesmerian mountain front in North Greenland: a basin margin inverted by basement uplift. J. struct. Geol. 12, 83-97.
Soper, N. J. \& Higgins, A. K. \& Friderichsen, J. D. 1980: The North Greenland fold belt in eastern Johannes V. Land. Rapp. Grønlands geol. Unders. 99, 89-98.

Springer, N. 1981: Preliminary Rb-Sr age determinations from the North Greenland fold belt, Johannes V. Jensen Land, with comments on the metamorphic grade. Rapp. Grønlands geol. Unders. 106, 77-84.

Steenfelt, A. 1980: The geochemistry of stream silt, North Greenland. Rapp. Grønlands geol. Unders. 99, 129-135.

Steenfelt, A. 1985: Reconnaissance scale geochemical survey in central and western North Greenland. Preliminary results concerning zinc and barium. Rapp. Grønlands geol. Unders. 126, 95-104.

Steenfelt, A. 1987: Geochemical trends in central and western North Greenland. Rapp. Grønlands geol. Unders. 133, 123132.

Tull, S. J. 1988: Conodont micropalaeontology of the Morris Bugt Group (Middle Ordovician - Early Silurian), North Greenland. Unpublished Ph.D. thesis, Univ. Nottingham, U.K., 367 pp.

Weng, W. L. 1980: Preliminary Bouguer anomalies of western North Greenland. Rapp. Grønlands geol. Unders. 99, 153154. 